Download

UDC 649

https://doi.org/10.17721/2308-135X.2020.6

$\underline{0.10-15}$

Budarina Kateryna Oleksiivna National University of Food Technologies, Kyiv, Ukraine

Sharan Larysa Oleksandrivna,

Candidate of Technical Sciences, Associate Professor National University of Food Technologies, Kyiv, Ukraine,

e-mail: Larisharan@ukr.net

Bondar Natalia Petrovna,

Candidate of Technical Sciences, Associate Professor National University of Food Technologies, Kyiv, Ukraine

Gubenya Vyacheslav Alexandrovich,

Candidate of Technical Sciences, Associate Professor National University of Food Technologies, Kyiv, Ukraine 


\section{EXPEDIENCY OF INTRODUCING A CRAFT CAVE IN A HOSPITALITY INSTITUTION}

Goal. The purpose of the article is to substantiate the feasibility of introducing a craft cafe on the basis of a business hotel, in particular, introducing the local stage of raw raw materials preparation in the technology of preparing coffee beans. Indeed, according to the study, the provision of services for organizing the preparation of a coffee drink in hotels is not satisfactory. And the quality of raw materials leaves much to be desired.

Methodology. The methodological basis of this work is the work of domestic and foreign scientists in the field of hospitality, scientific periodicals, Internet resources. The methodology includes generalizing and statistical data, which reflects the feasibility of introducing a preparatory operation for processing raw materials in the technology of making coffee precisely on the territory of a hospitality establishment.

Results. As a result of the research, the international and domestic experience of introducing a craft cafe in a business hotel was analyzed. It was found that there is no such practice of implementation in domestic and foreign hospitality establishments. An algorithm was developed for the introduction of a craft cafe, ways of using secondary raw materials in additional services were proposed, and the positive effect of coffee on the human body was confirmed. The results of the implementation will help improve the culture of coffee consumption and expand its range, while providing the hospitality enterprise with the opportunity to develop and make significant profits.

Scientific novelty. The necessity of introducing a craft cafe with its own roast on the territory of a hospitality enterprise has been proved. The world experience in the introduction of craft cafes in Ukraine has been systematized. The assortment of additional services that contribute to increasing the competitiveness of the institution, as well as which will enable business people during business trips to enjoy high-quality coffee drinks and maintain the beauty of their body, are presented.

Practical significance. The materials presented in the work can be used to improve and expand the range of additional services provided in domestic hospitality enterprises: to expand the range of coffee beans of our own production with different degrees of roasting for the manufacture of various coffee drinks, to reduce costs when purchasing batches of finished 
beans at auctions, while increasing their competitiveness not only in Ukraine, but also far beyond its borders.

Key words: hospitality enterprise, own coffee shop, additional services, competitiveness.

References:

1. Sergey Reminny. Coffee secrets. - Kyiv: 2016. - 608c. 2nd edition, supplemented.

2. Chemical composition and nutritional value of coffee [Electronic resource] - Mode of access to the resource: http://kavovakramnichka.blogspot.com/2013/01/blog-post_3337.

3. Degrees of roasting of coffee [Electronic resource] - Mode of access to the resource: https://brayval-coffee.com.ua/ua/raznaya-stepen-obzharki-kofe/

4. Equipment for coffee shop [Electronic resource] - Mode of access to the resource: https://olegiya.com.ua/ua/articles/biznec-ideya-vidkruvaemo-kavyarnu-z-nylya.html

Надійшла до редколегії 13.12.2020 